\author{
Ye.A. Issabayev ${ }^{1}$, A.K. Merekenova ${ }^{1}$, G.I. Boiko ${ }^{1}$, N.P. Lyubchenko ${ }^{1}$, \\ R.G. Sarmurzina ${ }^{2}$, Ye.M. Shaikhutdinov ${ }^{1}$ \\ ${ }^{1}$ Satbayev University, Almaty, Kazakhstan; \\ ${ }^{2}$ Association Kazenergy, Astana, Kazakhstan \\ (E-mail: amtek@bk.ru)
}

\title{
Scale inhibitor testing of new organophosphoric compounds
}

\begin{abstract}
A new generation of organophosphorous scale inhibitors has been developed. Inhibitors are intended to prevent the deposition of sulphate and carbonate salts in surface and downhole equipment during oil production, treatment and transportation. The I type inhibitor (aminophosphonic acid) was synthesized through the Moedritzer-Irani reaction of the condensation of 4.4'- (propane-2.2-diylbis(4.1-phenylene)bis(oxy)dianiline (A diamine) with formaldehyde and phosphorous acid, the II type inhibitor by phosphorylation of glycolyzed PET flex-(bis-hydroxyethyl terephthalate) with polyphosphoric acid. The structure of the developed organophosphorus compounds was confirmed by IR spectroscopy. High inhibitory efficacy of the first and second types of reagents for the deposition of carbonate and calcium sulphates was revealed. The morphology of the solid sediments of mineral salts was studied by scanning electron microscopy (SEM). It is revealed that the inhibition of crystal formation occurs at the stage of nucleation. Embedding in the surface of crystal nucleus, the inhibitors prevent formation of crystalline phase in a solution and crystal growth.
\end{abstract}

Keywords: organophosphoric compounds, aminophosphonic acid, phosphoric acid ester, scaling inhibitors, synthesis, reaction of Moedritzer-Irani, glycolyze, testing.

\section{Introduction}

Oil production in Kazakhstan has been steadily increasing over the last several years, while the average water cut of oil wells has been increasing, for some fields, water cut exceeds $90 \%$ [1]. As a result of increased water cutting of the extracted products, the inorganic salt scale precipitation on the surface of pumping equipment, infield equipment, in production columns, in oil collection and treatment systems increases that result in a failure of expensive equipment, capital expenditures on equipment repair, and decline in oil production [2].

The efficiency of suppression of scale inhibitors is comprehensive, taking into account physical and chemical processes, the composition of produced water, development of wells, etc. Preferred method of combating scale buildup is inhibitor protection that refers to preventative methods [3].

Inorganic compounds, different classes of organic compounds can be scale inhibitors, but the compounds based on derivatives of phosphonic and phosphoric acids have received the greatest distribution, as these compounds are capable of forming complex compounds with salt-forming cations and preventing their interaction with salt- forming anions [4].

In this paper, we present the results of a comparative evaluation of the effectiveness of protection against the deposition of sulphate and carbonate salts by new organophosphoric compounds of 2 types aminophosphonic acid and phosphoric ester of bis-hydroxyethyl terephthalate.

\section{Experimental}

Reagents and materials. Phosphonic acid 98+\% (Alfa Aesar, Karlsruhe, Germany); formaldehyde, aqueous $37 \%$ solution (Sigma-Aldrich); 4,4'-(propane-2,2-diylbis(4,1-phenylene)bis(oxy)dianiline (diamine A) the product purity is $99.9 \%$ by ${ }^{1} \mathrm{H}$ NMR spectroscopy; bis-hydroxyethylterephthalate obtained by the glycolysis reaction with ethylene glycol of a secondary PET flex, the structure of the product was confirmed by FTIR spectroscopy; polyphosphoric acid 115 \% (Sigma-Aldrich); sodium chloride, State Standard 23377; hexavalent magnesium chloride State Standard 4209-77; sodium bicarbonate State Standard; calcium chloride, dehydrated State Standard 6-09-47-11-81: ethylenediaminetetraphosphonic acid (EDTA); filtering paper; distilled water; laboratory scales in accordance with State Standard 24104-01.

Synthesis of organophosphates. Aminophosphonic acid was obtained by condensation of diamine A, formaldehyde and phosphorous acid through the Moedritzer-Irani reaction. The synthesis technique is described in the paper [5]. 
The phosphoric ester was obtained by phosphorylation of bis-hydroxyethylterephthalate with polyphosphoric acid. The synthesis technique is described in the paper [6]. The structure of synthesized organophosphates was confirmed by IR spectral analysis using Agilent Carry 660 IR spectrometer and Bruker Tensor II Fourier IR.

Static tests for scale inhibition [7]. The evaluation of the effectiveness of the scale inhibitor aminophosphonic acid against calcium carbonate and calcium sulphate deposits under static conditions was carried out according to previously described methods. The static laboratory method consists of precipitating $\mathrm{CaCO}_{3}$ and $\mathrm{CaSO}_{4}$ from water, i.e. heating with or without the presence of a scale inhibitor. In our work we used imitates of formation water of the chloride-calcium and sulphate-calcium type. The salt composition that simulates carbonate deposits is $\mathrm{Ca}^{2+}=1100 \mathrm{mg} / \mathrm{L}, \mathrm{Mg}^{2+}=380 \mathrm{mg} / \mathrm{L}, \mathrm{Na}^{+}=7500 \mathrm{mg} / \mathrm{L}, \mathrm{HCO}_{3}^{-}=$ $=976 \mathrm{mg} / \mathrm{L}, \mathrm{Cl}^{-}=14023 \mathrm{mg} / \mathrm{L}$. Two solutions are required to imitate scale formation. Solution 1 contains $3046 \mathrm{mg} / \mathrm{L}$ calcium chloride and hexavalent magnesium chloride $3177 \mathrm{mg} / \mathrm{L}$, while solution 2 is sodium chloride $18084 \mathrm{mg} / \mathrm{L}$ and sodium bicarbonate $1344 \mathrm{mg} / \mathrm{L}$.

The effectiveness of scale inhibition was determined for concentrations of $10,30,50,70,100,150$ or $200 \mathrm{ppm}$ of solution 1 in $50 \mathrm{~mL}$. This was mixed with $50 \mathrm{~mL}$ of solution 2 . Lids were placed on the flasks, and the temperature was fixed at $75{ }^{\circ} \mathrm{C}$ for 5 hours. Then the samples were filtered and the calcium ion content determined. $10 \mathrm{~mL}$ of filtrate were placed in the conical flasks and $40 \mathrm{~mL}$ of distilled water, $2.5 \mathrm{~mL}$ of $20 \%$ sodium hydroxide solution and $10-15 \mathrm{mg}$ of a mixture of murexide and sodium chloride were added. Secondly, the salt composition simulating sulphate (gypsum) deposits is $\mathrm{Ca}^{2+}=4911 \mathrm{mg} / \mathrm{L}, \mathrm{Mg}^{2+}=148 \mathrm{mg} / \mathrm{L}$, $\mathrm{Na}^{+}=11623 \mathrm{mg} / \mathrm{L}, \mathrm{SO}_{4}{ }^{2-}=8792 \mathrm{mg} / \mathrm{L}, \mathrm{Cl}^{-}=20291 \mathrm{mg} / \mathrm{L}$. To prepare the imitation of scale formation in this case, two further solutions are needed. Solution 3 is calcium chloride $1360 \mathrm{mg} / \mathrm{L}$, while solution 4 contains sodium chloride $18800 \mathrm{mg} / \mathrm{L}$, hexahydrate magnesium chloride $1240 \mathrm{mg} / \mathrm{L}$ and sodium sulphate $13000 \mathrm{mg} / \mathrm{L}$. The same procedure was carried out with solutions 3 and 4 as for solutions 1 and 2 . The content of calcium ions in each case is calculated by the formula:

$$
X=\frac{V_{t} \times N_{t} \times 20.04 \times 1000}{10},
$$

where $V_{t}$ - volume of EDTA-Na ${ }_{2}$, which went to titration, $\mathrm{ml} ; N_{t}$ - molar concentration of equivalent solution of EDTA-Na 2 , mol /L equivalent; 10 - volume taken for titration; 20,04 - molar mass of the equivalent of calcium ion, $\mathrm{g} / \mathrm{mol}$.

For comparison, the experiment is conducted in parallel without the addition of scale inhibitor. The effectiveness of the scale inhibitor (\%) is determined by the formula:

$$
E=\frac{C_{p}-C_{x}}{C_{0}-C_{x}} \times 100 \%,
$$

where $C_{x}$ - content of calcium ions in a sample that does not contain an inhibitor, $\mathrm{mg} / \mathrm{L} ; C_{p}$ - content of calcium ions in the sample containing the inhibitor, after thermostating, $\mathrm{mg} / \mathrm{L} ; C_{0}$ - content of calcium ions in the initial solution, $\mathrm{mg} / \mathrm{L}$.

\section{Results and discussion}

Well-known foreign technologies for controlling scale precipitation of mineral salts on the surface of process equipment at petrochemical complexes are based on the treatment of water with inorganic phosphate derivatives [8]. In water treatment systems for inorganic phosphates, there are environmental limitations in the concentration due to the fact that phosphates promote excessive growth of algae, oxygen deficiency and extinction of fish [9].

One of the safe water treatment technologies is the use of organic phosphates, such as phosphoric esters, phosphonic acids. Organic phosphates contain less phosphorus, are biodegradable, have low toxicity, are not inferior in efficiency to inorganic phosphates. For their properties, these compounds are classified as complexons, their complexing properties are realized due to the presence of hydrogen atoms of phosphonic groups [10]. According to [10], the mechanism of scaling inhibition by organophosphates can be explained by the formation of complex compounds with crystal nucleus of mineral salts. Inhibition occurs due to adsorption of organophosphates on the surface of growing crystals of mineral salts, which excludes the possibility of formation of a crystalline phase in a solution. The scheme for the complex formation of the phosphoric ester with calcium ions is shown in Figure 1. 
<smiles>O=P([O-])([O-])O[Al]OP(=O)([O-])[O-]</smiles><smiles>O=P1([O-])O[Al](O)O[W](=O)(=O)O[Al](O)O1</smiles>

Figure 1. Scheme of complexation of the phosphoric acid ester with calcium ions

The new organophosphonates that we developed were identified and characterized $[5,6]$. In order to confirm the structure, their IR spectral analysis was carried out. Figures 2 and 3 shows the IR spectra of aminophosphonic acid and phosphoric acid monoester of bis-hydroxyethylterephthalate, respectively.

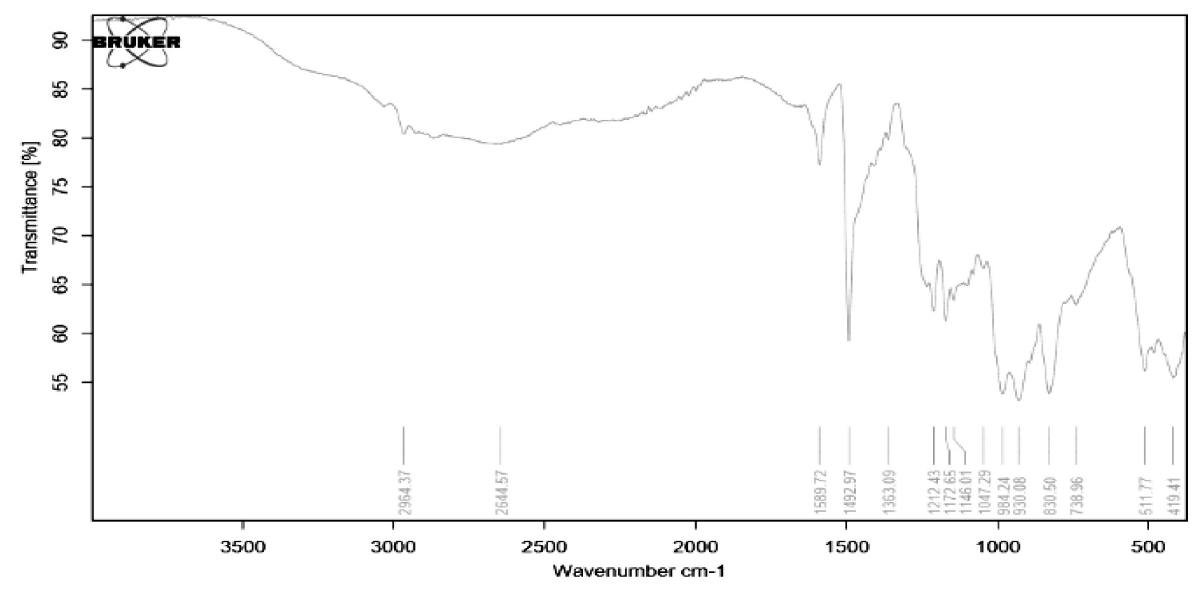

Figure 2. IR spectrum of aminophosphonic acid

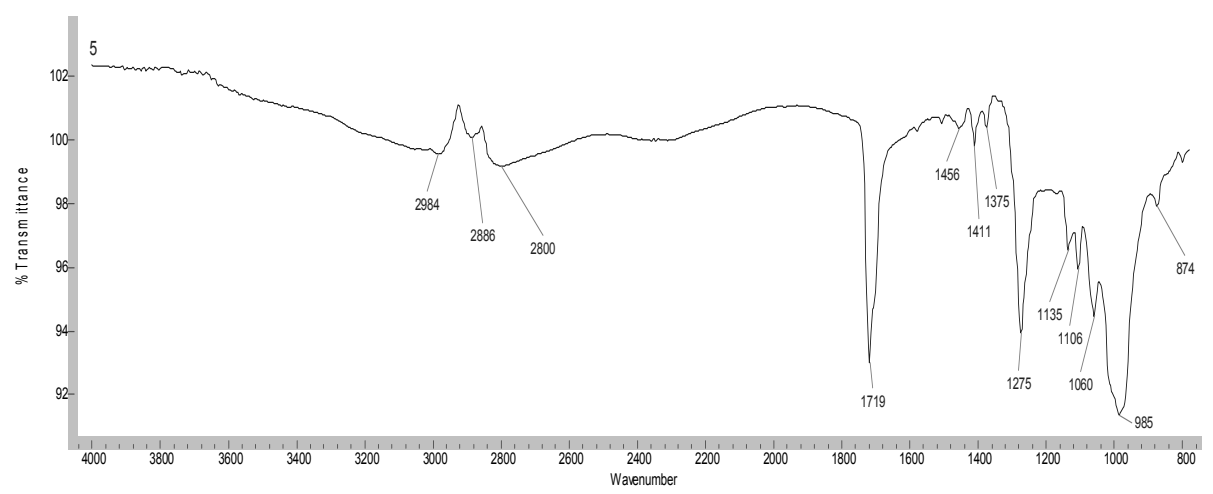

Figure 3. IR spectrum of phosphoric acid ester

The IR spectrum showed absorption bands in the $2964 \mathrm{~cm}^{-1}$ region attributable to stretching vibrations in the $-\mathrm{CH}_{3}$ and $-\mathrm{CH}_{2}$ groups. The absorption band at $1590 \mathrm{~cm}^{-1}$ indicates the stretching vibrations of the $\mathrm{C}=\mathrm{C}$ double bonds in the aromatic ring. The stretching vibrations at $1363 \mathrm{~cm}^{-1}$ correspond to the $\mathrm{C}-\mathrm{N}$ bonds. The absorption band at $1173 \mathrm{~cm}^{-1}$ shows the stretching vibrations of the $\mathrm{P}=\mathrm{O}$ group. The $738 \mathrm{~cm}^{-1}$ band describes the stretching vibrations of the P-C bond.

In the IR spectrum of the phosphoric ester of bis-hydroxyethylterephthalate, an absorption band is observed in the region of $1719 \mathrm{~cm}^{-1}$, which can be attributed to the stretching vibrations of the carbonyl group of the compound ester. The 2966, $2881 \mathrm{~cm}^{-1}$ bands are attributed to the vibrations of the $\mathrm{CH}$ bonds in the $\mathrm{CH}_{2}$ groups; in the region of $1504 \mathrm{~cm}^{-1}$, they are referred to vibrations in the aromatic ring, in the $2800 \mathrm{~cm}^{-1}$ region to the $\mathrm{P}-\mathrm{OH}$ deformation oscillations. Fluctuations in the region of $985 \mathrm{~cm}^{-1}$ can be attributed to the deformation in the $\mathrm{P}-\mathrm{OC}$ group, in the $1106 \mathrm{~cm}^{-1}$ region — to the stretching vibrations in $\mathrm{P}=\mathrm{O}$. 
Based on the data of IR spectroscopic studies, the expected chemical structure of the organophosphates was obtained (Fig. 4).

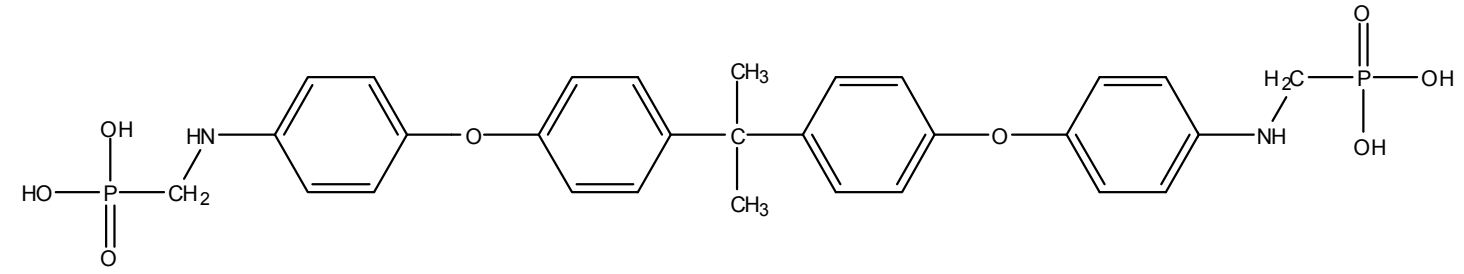

Propane-2,2 phenylene-diylbis bis(4,1)-phenylene)bis(4,1-bis(azadienyl)bis(methylene)diphosphonic acid (a)<smiles>O=C(OCCCOP(=O)(O)O)c1ccc(C(=O)OCCCOP(=O)(O)O)cc1</smiles>

$\operatorname{Bis}(2-($ phosphonooxyl)ethyl)terephthalate (b)

Figure 4. Alleged chemical structure of organophosphates: phosphoric acid ester of bis-hydroxyethyl terephthalate $(a)$ and aminophosphonic acid $(b)[5,6]$

In order to identify the scale inhibition ability, organophosphonic compounds have been tested on different models of produced water. The tests were carried out in model solutions at a temperature of $75^{\circ} \mathrm{C}$ and an inhibitor concentration from 10 to $200 \mathrm{ppm}$. The results of the inhibition studies are shown in Figures 5 and 6 . As the figures show, the new reagents exhibit a sufficiently high inhibitory activity with respect to the $\mathrm{CaCO}_{3}$ and $\mathrm{CaSO}_{4}$ deposits. At the same time, it can be noted that the inhibition efficiency on $\mathrm{CaCO}_{3}$ deposits was higher for aminophosphonic acid. The maximum protection at a concentration of $200 \mathrm{ppm}$ of this reagent was $94 \%$, and for the phosphoric ester at the same concentration was $85 \%$. However, the inhibition efficiency on $\mathrm{CaSO}_{4}$ deposits (Fig. 6) is much higher for phosphoric ester, the maximum efficiency was $100 \%$ and reached at a concentration of $30 \mathrm{ppm}$, the maximum inhibition degree for aminophosphonic acid was $97 \%$ at a concentration of $200 \mathrm{ppm}$.

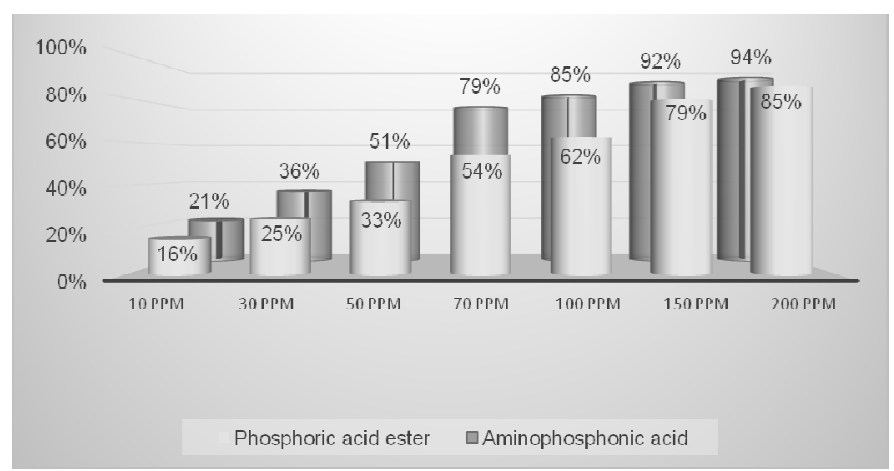

Figure 5. Effectiveness of inhibitors on $\mathrm{CaCO}_{3}$ deposits

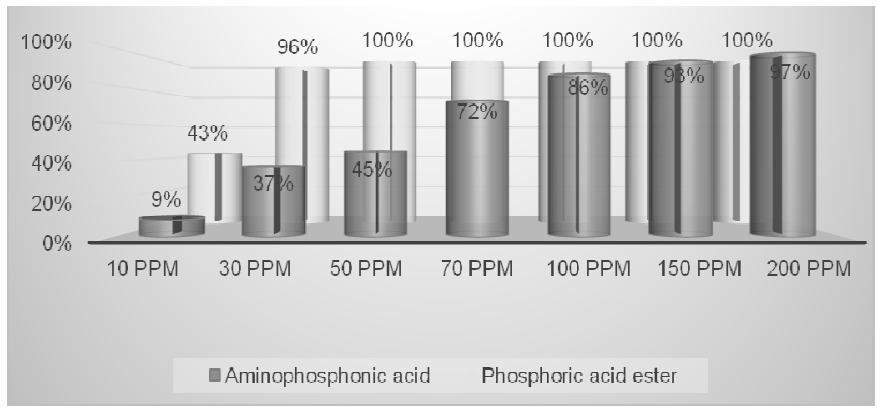

Figure 6. Effectiveness of inhibitors on $\mathrm{CaSO}_{4}$ deposits 
The reason for the different efficiency of the inhibitors was elucidated in the study of scale samples by scanning electron microscopy using a JEOL JSM-649OLV instrument. The authors [11] note that $\mathrm{CaCO}_{3}$ has the property of polymorphism, the precipitates have the same chemical composition, but they have different crystalline structures - calcite, aragonite and vaterite. Argonite, unlike vaterite, has a more stable crystalline form [12]. The vaterite under normal conditions $\left(25^{\circ} \mathrm{C}\right.$, atmospheric pressure $)$ eventually transforms into a more stable form of calcite, and at temperatures $\left(70-80^{\circ} \mathrm{C}\right)$ first transforms into aragonite, and then into calcite. Compared to calcite, aragonite and vaterite are soluble in water. This is due to the fact that aragonite and vaterite have a lower value of free surface energy as compared to calcite, which reduces their adhesion on the surface of the equipment, due to the interaction between the crystals [13]. Moreover, it was reported in [14-17] that under certain conditions occurrence of two more forms of calcium carbonate is possible: calcium carbonate monohydrate and calcium carbonate hexahydrate.

Figures 7, 8 and 9 shows micrographs of precipitation of mineral salts before and after treatment with inhibitors.

As can be seen on Figure 7, the difference in the formation of crystals is obvious. Crystals formed without an inhibitor are in the form of calcite. The phase composition of the precipitate obtained in the presence of aminophosphonate is characterized by a higher content of aragonite and vaterite. For the phosphoric ester, there are preferably more crystals in the form of vaterite. Also, from Fig. 6 for aminophosphonic acid and phosphoric ester, it follows that these compounds have complexing properties and are able to be embedded in the surface of the crystallization nucleus, as a result of which crystal growth ceases.

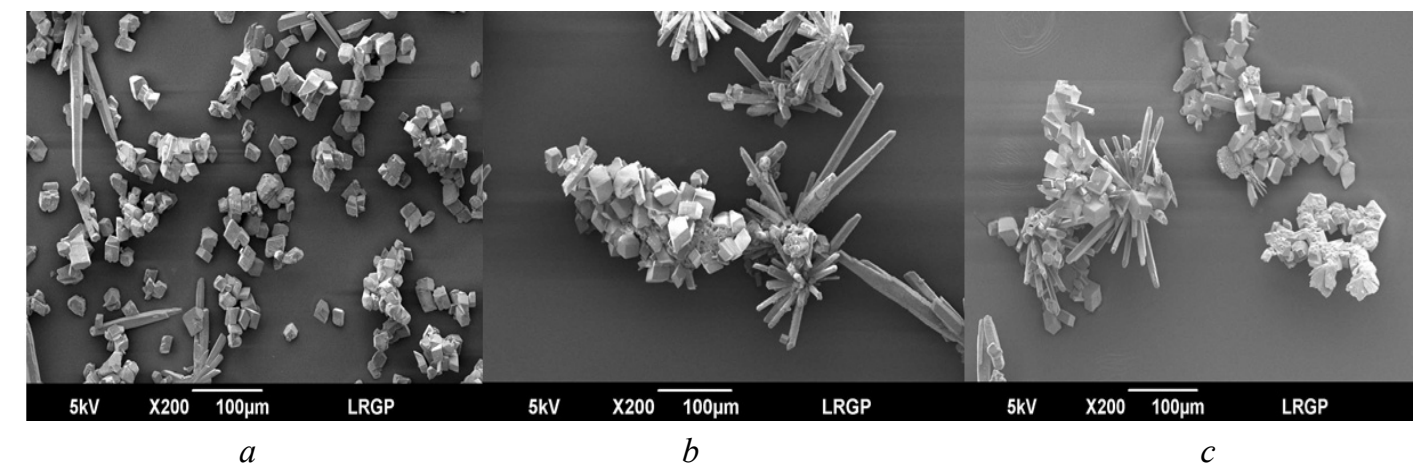

$a$ - blank; $b$ - phosphoric acid ester (30 ppm); $c$ - aminophosphonic acid 30 ppm

Figure 7. Micrographs of carbonate sediments without an inhibitor and with scaling inhibitors

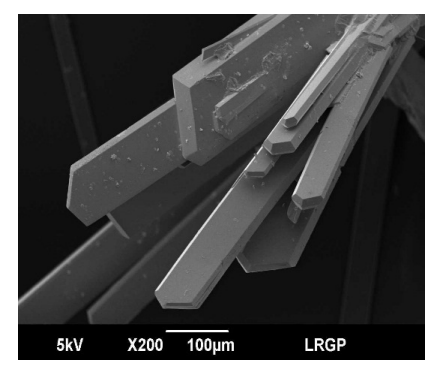

$a$

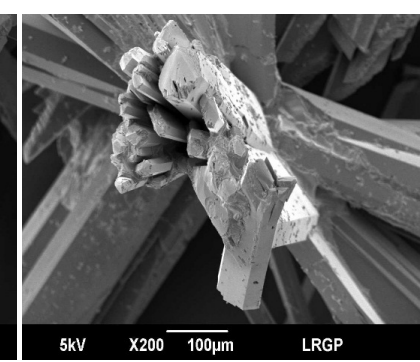

$b$

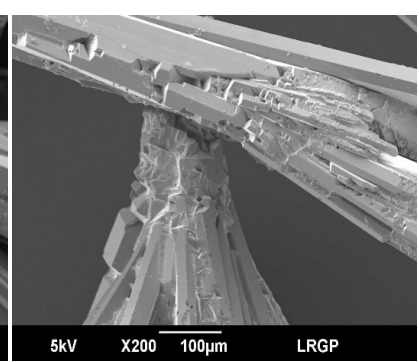

C

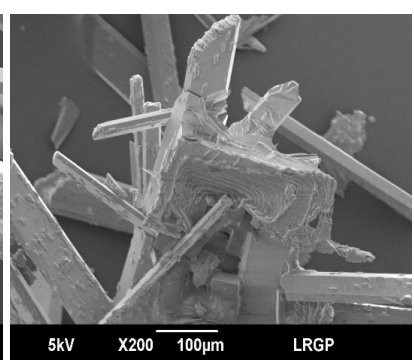

$d$

$a-$ blank; after addition of phosphoric acid ester; $b-5 \mathrm{ppm} ; c-10 \mathrm{ppm} ; d-20 \mathrm{ppm}$

Figure 8. Microphotographs of sulfate sediments

Figure $8 a$ shows that the structure of deposits of sulphate sediments without an inhibitor has structures in the form of smooth needles. When phosphoric ester inhibitors were added, the destruction of gypsum deposits started (Figure $8 b, 8 c, 8 d$ ). Complete destruction of the deposit was achieved at a concentration of $30 \mathrm{ppm}$. A similar effect was observed for aminophosphonic acid (Fig. 9), but in this case the concentration of the reagent was higher than that of the phosphoric ester (Fig. $9 a, b, c$ ). The beginning of destruction of sulphate sediments was observed at a concentration of $10 \mathrm{ppm}$. Complete destruction was noted at $200 \mathrm{ppm}$. 


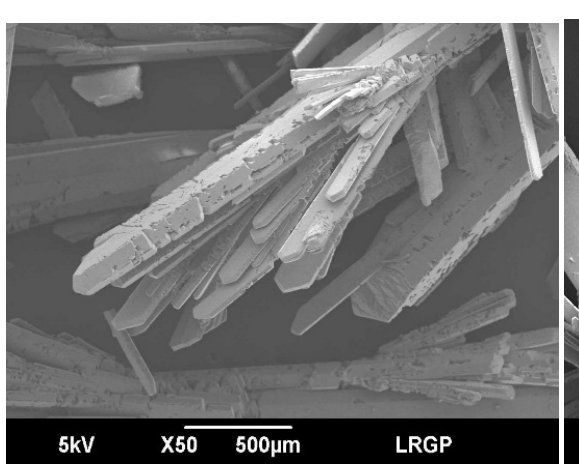

$a-10 \mathrm{ppm}$

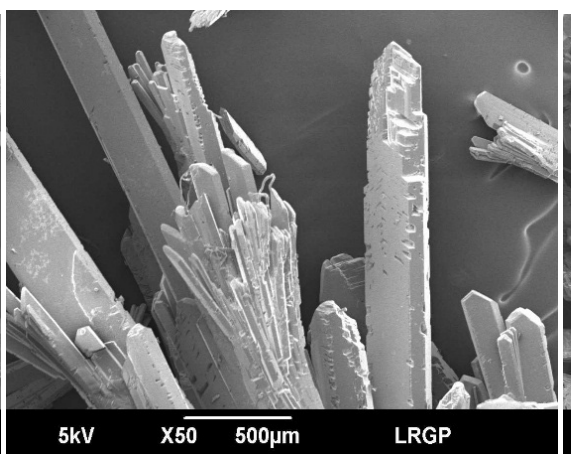

$b-100 \mathrm{ppm}$

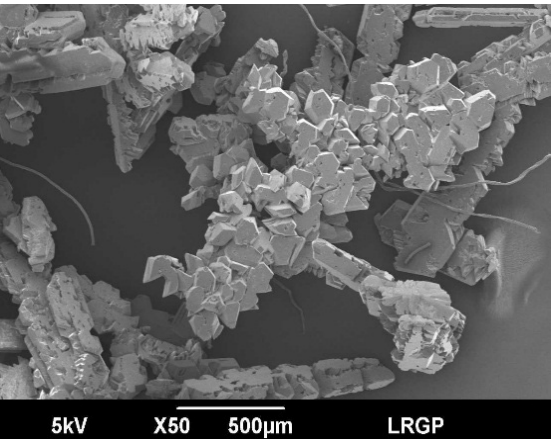

$c-150 \mathrm{ppm}$

Figure 9. Microphotographs of sulfate sediments without inhibitor

Thus, it was shown that inhibitors have not only high inhibitory properties with respect to carbonate and calcium sulphate deposition, but are also capable of altering the morphology of crystals, which favorably affects the destruction of already fallen salt crystals and their removal with process fluid.

The inhibitors are highly effective for total deposits of carbonate salts (94 and $85 \%$ ) and sulphates (97 and $100 \%$ ) at a concentration of $200 \mathrm{ppm}$.

\section{References}

1 Сармурзина Р.Г. Композиционные реагенты для разрушения сложных водонефтяных эмульсий месторождений Западного Казахстана / Р.Г. Сармурзина, У.С. Карабалин, Б.У. Акчулаков, Г.И. Бойко, Н.П. Любченко, Е.С. Панова // НефтеГазоХимия. - 2016. — № 4. - С. 45-50.

2 Ибрагимов Н.Г. Осложнения в нефтедобыче: монография / Н.Г. Ибрагимов, А.Р. Хафизов, В.В. Шайдаков. - Уфа, 2003. - 302 c.

3 Кащавцев В.Е. Солеобразование при добыче нефти / В.Е. Кащавцев, И.Т. Мищенко. — М.: Орбита-М, 2004. — 432 с.

4 Кабачник М.И. Органофосфорные комплексоны / М.И. Кабачник, Т.Я. Медведь, Н.М. Дятлова, М.В. Рудомино // Успехи химии. - 1974. - № 9. - С. 1554-1574.

5 Issabayev Ye.A. New organophosphorous inhibitor to prevent scaling and coagulants for water purification / Ye.A. Issabayev, G.I. Boiko, N.P. Lyubchenko, M. Hervé, M.T. Baygaziyev, R.G. Sarmurzina, Ye.M. Shaikhutdinov // 16ème congrès de la société Française de génie des proceeds (11-13 July 2017). — Nancy, Lorraine: ENSIC, 2017. — P. 428, 429.

6 Merekenova A.K. Modified polyethyleneterephtalate waste, a new scale and corrosion inhibitors / A.K. Merekenova, G.I. Boiko, N.P. Lyubchenko, G.B. Sagiyeva // Special polymers for environment protection, oil industry, bio-nanotechnology and medicine: Proceedings of the VII international Workshop (7-9 September 2017). — Almaty: Satbayev University, 2017. — P. 39.

7 Стандарт «Порядок проведения лабораторных и опытно-промысловых испытаний химических реагентов для применения в процессах добычи и подготовки нефти и газа»: СТ-07.1-00-00-04 ОАОАНК «Башнефть». - [Введен в действие от 2014-09-23]. - Уфа: ОАО АНК «Башнефть», 2014. — 88 с. — (Внутренний стандарт).

8 Фрог Б.Н. Водоподготовка: учеб. пос. / Б.Н. Фрог, А.П. Левченко. — М.: Изд-во МГУ, 1996. — 606 с.

9 Бондарь Ю.Ф. Применение фосфорорганических соединений для борьбы с накипеобразованием в оборотных системах охлаждения / Ю.Ф. Бондарь, В.П. Маклакова, Р.К. Гронский // Теплоэнергетика. — 1976. — № 1. — С. 70-73.

10 Дятлова Н.М. Комплексоны и комплексонаты металлов / Н.М. Дятлова, В.Я. Темкина, К.И. Попов. — М.: Химия, 1988. - $543 \mathrm{c}$.

11 Ogino T. The formation and transformation mechanism of calcium carbonate in water / T. Ogino, T. Suzuki, K. Sawada // Geochim et Cosmochim Acta. — 1987. - Iss. 5. - P. 2757-2767.

12 Воробьёв А.Д. Особенности кристаллизации карбоната кальция в присутствии органических фосфатов и карбоновых кислот / А.Д. Воробьёв, О.Б. Дормешкин, Ю.В. Матрунчик, Н.П. Крутько // Вестн. Нац. акад. навук Беларусі. Сер. хім. навук. - 2014. - № 1. - С. 101-107.

13 Карбонаты. Минералогия и химия / под ред. Р.Дж. Ридера. — М.: Мир, 1987. — 496 с.

14 Brecevic L. On Calcium Carbonates: from Fundamental Research to Application / L. Brecevic, D. Kralj // Croat. Chem. Acta. - 2007. - Iss. 80. - P. 467-484.

15 Giannimaras E.K. Precipitation of calcium carbonate in aqueous-solutions in the presence of oxalate anions / E.K. Giannimaras. P.G. Koutsoukos // Langmuir. — 1988. — Vol. 4, Iss. 4. — P. 855-861.

16 Hull H. Thermochemical Study of Monohydrocalcite / H. Hull, A.G. Turnbull // Geochim. Cosmochim. Acta. — 1973. — Vol. 37. - P. 685-694.

17 Amjad Z. Evaluation of maleic acid based polymers as scale inhibitors and dispersants for industrial water applications / Z. Amjad, P. Koutsoukos // Desalination. - 2014. — Iss. 335. - P. 55-63. 


\title{
Е.А. Исабаев, А.К. Мерекенова, Г.И. Бойко, Н.П. Любченко, Р.Г. Сармурзина, Е.М. Шайқұтдінов \\ Тұз шөгінділерінін ингибиторлары ретіндегі жаңа фосфорлы органикалық қосылыстардың сынақтары
}

\begin{abstract}
Мұнай өндіру, дайындау және тасымалдау барысында қолданылатын жер бетіндегі және ұңғымадағы қондырғыларды сульфатты және карбонатты тұздардың шөгінділерінен қорғайтын, жаңа буындағы фосфорлы органикалық тұз шөгінділерінің ингибиторы жасап шығарылды. Бірінші түрлі ингибитор (аминфосфон қышқылы) Моедритцер-Ирани реакциясы арқылы 4,4'-(пропан-2,2-диилбис(4,1фенилен)бис(окси)дианилиннің (диамин А) формальдегидпен және фосфорқышқылымен конденсациялау арқылы синтезделді, екіншісі - гликолизденген ПЭТ флексін - полифосфор қышқылының бисгидроксиэтилтерефталатын фосфорлау арқылы. Жасалған фосфорлы органикалық қосылыстарының құрылымы ИҚ-спектроскопия әдісімен расталған. Сканерлеуші электронды микроскопия арқылы (РЭМ) минералды тұздардың қатты тұнбаларының морфологиясы зерттелді. Кристалл түзілуінің тежелуі ядро түзілу сатысында орын алатыны анықталды. Кристалл ядроларының бетіне кірістірілуі арқылы ингибиторлар ерітіндідегі кристалдық фазаның түзілуін және кристалдардың өсуін болдырмайды.
\end{abstract}

Кілт сөздер: фосфорлы органикалық қосылыстар, аминофосфон қышқылы, фосфор қышқылының күрделі эфирі, тұз шөгінділері ингибиторлары, синтез, Моедритцер-Ирани реакциясы, гликолиз, тестілеу.

\author{
Е.А. Исабаев, А.К. Мерекенова, Г.И. Бойко, Н.П. Любченко, \\ Р.Г. Сармурзина, Е.М. Шайхутдинов
}

\section{Испытания новых органофосфорных соединений в качестве ингибиторов солеотложений}

\begin{abstract}
Разработаны органофосфорные ингибиторы солеотложений нового поколения, предназначенные для предотвращения отложений сульфатных и карбонатных солей в наземном и скважинном оборудовании при нефтедобыче, подготовке и транспорте нефти. Ингибитор первого типа (аминофосфоновая кислота) был синтезирован по реакции Моедритцера-Ирани конденсацией 4,4'(пропан-2,2-диил-бис(4,1-фенилен)-бис(окси)дианилина (диамина А) с формальдегидом и фосфористой кислотой, второго - фосфорилированием гликолизированного ПЭТ флекса - бис-гидроксиэтилтерефталата полифосфорной кислотой. Структура разработанных органофосфорных соединений подтверждена методом ИК-спектроскопии. Растровой электронной микроскопией (РЭМ) изучена морфология твердых осадков минеральных солей. Выявлено, что ингибирование кристаллообразования происходит на стадии зародышеобразования. Встраиваясь в поверхность зародышей кристалла, ингибиторы препятствуют образованию кристаллической фазы в растворе и росту кристаллов.
\end{abstract}

Ключевые слова: органофосфорные соединения, аминофосфоновая кислота, сложный эфир фосфорной кислоты, ингибиторы солеотложения, синтез, реакция Моедритцера-Ирани, гликолиз, тестирование.

\section{References}

1 Sarmurzina, R.G., Karabalin, U.S., Akchulakov, B.U., Boyko, G.I., Lyubchenko, N.P., \& Panova, Ye.S. (2016). Kompozitsionnye reahenty dlia razrusheniia slozhnykh vodoneftianykh emulsii mestorozhdenii Zapadnoho Kazakhstana [Composite reagents for the destruction of complex oil-water emulsion of the oil fields in Western Kazakhstan]. NefteHazoKhimiia — Oil \& Gas chemistry, 4, 45-50 [in Russian].

2 Ibragimov, N., Gafizov, A.R., \& Shaidakov, V.V. (2003). Oslozhneniia v neftedobyche [Complications in oil production]. Ufa [in Russian].

3 Kashchavtsev, V.E., \& Mishchenko, I.T. (2004). Soleobrazovanie pri dobyche nefti [Salt formation during oil production]. Moscow: Orbita-M [in Russian].

4 Kabanchik, M.I., Medved, T.Ya., Diatlova, N.M., \& Rudomino, M.V. (1974). Orhanofosfornye kompleksony [Organophosphorus complexones]. Uspekhi khimii - Success of chemistry, 9, 1554-1574 [in Russian].

5 Issabayev, Ye.A., Boiko, G.I., Lyubchenko, N.P., Hervé, M., Baygaziyev, M.T., Sarmurzina, R.G. \& Shaikhutdinov, Ye.M. (Eds.) (2017). Proceedings from: 16ème congrès de la société Française de génie des proceed, Nancy, 11-13 July 2017. Lorraine: ENSIC.

6 Merekenova, A.K., Boiko, G.I., Lyubchenko, N.P., \& Sagiyeva, G.B. (Eds.) (2017). Proceedings of the VII International Workshop, Almaty, 7-9 September 2017. Almaty: Satbayev University. 
7 Poriadok provedeniia laboratornykh i opytno-promyslovykh ispytanii khimicheskikh reahentov dlia primeneniia $\mathrm{v}$ protsessakh dobychi $\mathrm{i}$ podhotovki nefti i haza [Procedure for carrying out laboratory and experimental testing of chemical reagents for use in oil and gas production and treatment processes]. (2014) ST-07.1-00-00-04 from $23^{\text {th }}$ September. Ufa: OAO ANK «Bashneft» [in Russian].

8 Froh, B.N., \& Levchenko, A.P. (1996). Vodopodhotovka [Water preparation]. Moscow: Izdatelstvo MHU [in Russian].

9 Bondar, Yu.F., Maklakova, V.P,. \& Gronskii, R.K. (1976). Primenenie fosfororhanicheskikh soedinenii dlia borby s nakipeobrazovaniem $\mathrm{v}$ oborotnykh sistemakh okhlazhdeniia [The use of organophosphorus compounds to combat scale formation in circulating cooling systems]. Teploenerhetika. - Heat power engineering, 1, 70-73 [in Russian].

10 Diatlova, N.M., Temkina, V.Ya., \& Popov, K.I. (1988). Kompleksony i kompleksonaty metallov [Chelators and metals complexonates]. Moscow: Khimiia [in Russian].

11 Ogino, T. (1987). The formation and transformation mechanism of calcium carbonate in water. Geochim et Cosmochim Acta, $5,2757-2767$.

12 Vorobev, A.D., Dormeshkin, O.B., Matrunchik, Yu.V., \& Krutko, N.P. (2014). Osobennosti kristallizatsii karbonata kaltsia v prisutstvii organicheskikh fosfatov $\mathrm{i}$ karbonovykh kislot [Features of the crystallization of calcium carbonate in the presence of organic phosphates and carboxylic acids]. Vestnik Natsionalnoi akademii nauk Belarusi - Herald of the National Academy of Sciences of Belarus, 1, 101-107 [In Russian].

13 Rider, R. Dzh. (Eds). (1987). Mineralohiia i khimiia [Mineralogy and chemistry]. Moscow: Mir [In Russian].

14 Brecevic, L., \& Kralj, D. (2007). On Calcium Carbonates: from Fundamental Research to Application. Croat. Chem. Acta., $80,467-484$.

15 Giannimaras, E.K., \& Koutsoukos P.G. (1988). Precipitation of calcium carbonate in aqueous-solutions in the presence of oxalate anions. Langmuir, 4(4), 855-861.

16 Hull, H., \& Turnbull A.G. (1973). Thermochemical Study of Monohydrocalcite. Geochim. Cosmochim. Acta, 37, 685-694.

17 Amjad Z., \& Koutsoukos, P. (2014). Evaluation of maleic acid based polymers as scale inhibitors and dispersants for industrial water applications. Desalination, 335, 55-63. 